DOI: 10.22559/folklor.896

folklor/edebiyat, cilt:25, sayı:99, 2019/3

\title{
Dişi Kurdun Rüyaları ve Infaza Çağrı Adlı Romanlarda Birey-Toplum Çatışması
}

\section{The Individual-Society Conflict in The Place of the Skull and Invitation to a Beheading}

\section{Abdurrahman Kolcu*}

\section{Öz}

20. yüzyıla damgasını vuran totaliter rejimlerin kitleler ve birey üzerindeki etkisini, edebî eserlerde de takip edebilmek mümkündür. Bu bağlamda doğrudan doğruya belirli bir rejimin eleştirisini örnekleyen eserlerin yanında, kimi eserlerde bir distopya tasarımı içinde dolaylı bir anlatım ve göndermelerle de benzer eleştirel yaklaşımların sergilendiği görülmektedir. Bu tespiti örneklemek adına bu makalede doğrudan doğruya belirli bir rejimin eleştirisini içeren Cengiz Aytmatov'un Dişi Kurdun Rüyala$r l$ ile distopya tasarımı içinde dolaylı bir şekilde kendi çağındaki totaliter rejimleri eleştiren Vladimir Nabokov'un İnfaza Çağrl adlı romanları karşılaştırılmıştır. Bu iki romanda da 20. yüzyıldaki totaliter rejimlere doğrudan veya dolaylı bir şekilde eleştiri yöneltilir. Birey baskıcı bir rejimle ve onun yansıması olan bir toplumsal yapıyla yüzleşmek ve çarpışmak durumunda kalır. Bireyin örgütlü topluma karşı bu mücadelesi yenilgiyle sonuçlanır ve böyle bir toplumda yaşaması, hayatını istediği gibi devam ettirebilmesi mümkün olamaz. İşte bütün bu süreç değişik ayrıntılarla her iki eserde ele alınır. Bu makalede bütün bu hususlar ayrıntılı bir şekilde incelenmektedir.

Anahtar sözcükler: Dişi Kurdun Rüyaları, Cengiz Aytmatov, Infaza Çağrı, Vladimir Nabokov, karşılaştırmalı edebiyat

* Doç. Dr., Recep Tayyip Erdoğan Üniversitesi Fen-Edebiyat Fakültesi Türk Dili ve Edebiyatı Bölümü, abdkoller@gmail.com 


\begin{abstract}
It is possible to follow the effect of the totalitarian regimes that marked the 20th century on the masses and the individual in literary works. In this context, besides the works that exemplify the criticism of a particular regime, it is possible to say that in some works, similar critical approaches are displayed in a dystopian design with indirect narrations and references. In order to exemplify this finding, this article reviews Vladimir Nabokov's Invitation to a Beheading which indirectly criticizes the totalitarian regimes of his own age in the dystopian design and Cengiz Aytmatov's The Place of the Skull which includes the critique of a particular regime. In these two novels, criticism is directed directly or indirectly to totalitarian regimes in the 20th century. The individual has to face and collide with a repressive regime and its social structure. This struggle of the individual against the organized society will result in defeat and it will not be possible for him to live in such a society and to continue his life as he wishes. This whole process is discussed in both works with different details. In this article all these issues are examined in detail.
\end{abstract}

Keywords: The Place of the Skull, Cengiz Aytmatov, Invitation to a Beheading, Vladimir Nabokov, comparative literature

\title{
Giriş
}

Bireyin içinde yer aldığı toplumun ya da yerleşik düzenin değerleri ve zihniyetiyle uyuşmaması, ister yanlış ister doğru olsun farklı zihniyet ve değerlere sahip olması, toplum ile kuracağı ilişkinin bir çatışma halini almasına zemin hazırlar. Her insanın hayatında az veya çok yaşadığı bu çatışmanın dünya tarihinde Sokrates’ten Galile’ye, Hz. İsa'dan Hallâc-1 Mansur'a çok sayıda önemli kişilikte tarihe mal olacak denli ileri boyutlara vardığını söylemek mümkündür. Bu çatışma aynı zamanda hayata ayna tutan edebiyatın da önemli temalarından birini oluşturur. Özellikle de roman türünde Don Kişot'tan günümüze değin bu çatışmanın ayrıntılı ve çok yönlü bir şekilde ele alındığı görülmektedir. Bu bağlamda temelde iki kategoriden söz etmek mümkündür. İlk kategoride, bireyin yanlış zihniyet ve yaklaşımlarla toplumun ya da yerleşik düzenin değer ve kurallarına yaptığı saldırı yer alır. Diğer kategoride ise yanlış bir zihniyeti ve kuralları dayatan toplum ya da yerleşik düzenin kendisinden farklı zihniyet ve yaklaşımlara sahip olan bireye yaptığı saldırı söz konusudur. Bizzat Don Kişot bu çatışmanın ilk kategorisini çok çarpıcı bir şekilde örneklemektedir. Okuduğu şövalye kitaplarıyla zihni bulanan, yaşadığı çağın gerisindeki bir dönemin bilincine sahip olan Don Kişot'un serüveni yanlış bir zihniyete sahip olmakla birlikte, bireyin toplumla olan mücadelesinin bir örneğidir. İşte bunun tam karşısındaki kategoride ise, birey-toplum çatışmasında bu kez toplumun Don Kişot'unki gibi yanlış bir içeriğin savunuculuğunu yaptığı ve bireyin bu kez doğrunun ve gerçeğin tarafında konumlandığı örnekler yer alır. Özellikle 20. yüzyılda totaliter rejimlerle yönetilen ülkelerdeki hayatın bu tür örneklere uygun bir zemin teşkil ettiğini söylemek gerekir.

20. yüzyılda totaliter ideolojiler, Rusya, İtalya, Almanya ve Çin gibi birçok ülkede devlet düzeni haline gelmiştir. II. Dünya Savaşı ve akabinde Berlin Duvarı'nın yıkılışına değin süren Soğuk Savaş’ta başlıca aktörler arasında totaliter ideolojilerle yönetilen ve diktatörleriyle özdeşleşen ülkeler vardır. Bu açıdan bakıldığında 20. yüzyıl dünya tarihindeki etkileri de 
aşikârdır. İdeolojileri ve diktatörleri farklı olsa da bu rejimlerin kendi paradigmalarını hâkim ve geçerli kılmak adına bireyin baskı altına alınması hususunda ortak bir paydada birleştiklerini söylemek mümkündür. Bu süreç tarihçilerin, ekonomistlerin ve siyaset bilimcilerin akademik çalışmalarına olduğu kadar sanata ve elbette ki edebiyata da malzeme teşkil etmiştir. Bu bağlamda, bu çalışmada birey-toplum çatışması ekseninde, totaliter bir rejim altında yan1ış bir içeriğin dayatması altında kalan bireyin durumunu merkeze alan Cengiz Aytmatov'un Dişi Kurdun Rüyaları adıyla dilimize aktarılan romanı ile Vladimir Nabokov'un İnfaza Çăgrı adıyla dilimize çevrilen romanı karşılaştırmalı bir şekilde incelenecektir.

\section{Dişi Kurdun Rüyaları}

Cengiz Aytmatov'un Türkçeye Dişi Kurdun Rüyaları adıyla çevrilen bu romanı Rusça yazılmış olup romanın orijinal adı Plaha'dır. Türkçe'nin farklı lehçelerine Kıyamet, Künde, Cellat Kütüğü gibi adlarla çevrilen (Kolcu, 2008: 256) romanın temelde üç öykünün bileşiminden oluştuğunu söylemek mümkündür. İlki, din konusundaki farklı görüşleri nedeniyle papaz okulundan uzaklaştırılan ve bir şekilde aralarına katıldığı uyuşturucu kaçakçıları ile sayga sürülerini avlayanları doğru yola eriştirme arzusu çarmıha gerilmesiyle sonuçlanan Abdias'ın öyküsüdür. Abdias'ın öyküsüyle ilişkili olarak Hz. İsa'nın çarmıha gerilmeden önce Roma'nın Kudüs Valisi ile yaptığı konuşmalar da romanın kurgu dünyası içinde değerlendirilmektedir.

İkinci öykü dişi kurt Akbar'ın erkek kurt Taşçaynar ile kurduğu yuva ve yavrularını bir türlü yaşatamamasının dramıdır. Sonuncusu ise koyun çobanı Boston Urkunçiyev’in düzenli yaşamının Akbar'ın yavrularının yuvalarından çalınmasından sonra bir trajediye dönüşen öyküsüdür. Dişi kurt Akbar'ın yazgısı yalnız koyun çobanı Boston'unkiyle değil, aşağıda ayrıntılı bir şekilde açıklanacağı üzere aynı zamanda Abdias’’nkiyle de kesişmektedir.

\section{Infaza Çăgrı}

Vladimir Nabokov, 1989'da Infaza Çă̆rı adıyla dilimize çevrilen ve özgün Rusça adı Priglaşenyi Na Kazn olan romanını önce Paris’te çıkan Sovremenniya Zapiski adlı bir Rus göçmen dergisinde tefrika eder (Nabokov, 1989: 5). Kitap 1938 yılında ise Don Knigi tarafından aynı kentte yayımlanır. Yazar eserin İngilizce çevirisinin önsözünde romanın yayımlanma ve çevrilme sürecine 1şık tutar (Nabokov, 1963: 7). Çeviri, yazarın birçok eserinde olduğu gibi yazarla işbirliği içinde, oğlu Dimitri Nabokov tarafından gerçekleştirilir. Eserin ABD'de İngilizce ilk baskısı G. P. Putnam's Sons tarafından 1959 yılında yapılır. Penguin Books'ta ise 1963 yılında yayımlanır.

Distopik bir eser olan İnfaza Çă̆rı'nın başkahramanı Cincinnatus C.'dir. Roman idam hükmünün onun kulağına ak saçlı yargıç tarafindan fisıldanarak bildirilmesiyle başlar. Sonrasında hücrede bir başına tutulduğu kaleye geri getirilen Cincinnatus'un idamının gerçekleşeceği güne kadar geçen hapis hayatının detayları ve ayrıntıları romanın ilerleyen sayfalarında verilmeye başlar. Dolayısıyla romanda onun 20 günlük hapis hayatı ve 30 yıllık yaşamından kesitler aktarılmaktadır. Romanın son bölümünde Cincinnatus, idam sehpasına uzanır, ancak sonrasinda oradan kalkar ve roman belirsiz bir sonla biter. 


\section{Yerleşik düzenle çatışma}

Bu çalışmada eseri incelenen her iki yazarın da hayatında aynı totaliter devlet yani Sovyetler Birliği derin bir travmaya yol açmıştır. Aytmatov'un babası, Stalin’in 1937 kıyımında tutuklanıp kurşuna dizilen aydınlardan biridir (Kolcu, 2008: 23). Zengin bir aristokrat aileye mensup olan Nabokov ise Bolşevik Devrimi’nden sonra bütün mal varlığını kaybedip, ailece önce Londra'ya akabinde Berlin'e göçmüş ve orada eski bir bakan olan babası, yine Bolşevik Devrimi ve Çar'ın öldürülmesiyle ilgili olan ama kendisini hedef almayan bir suikast esnasındaki karışıklıkta vurularak hayatını kaybetmiştir (Pitzer, 2013: 121). Dolayısıyla her iki yazar açısından da totaliter devlet yapısına ilişkin eleştirinin, onların yaşamlarında da karşılığının veya zemininin bulunduğunu belirtmek gerekir.

Ellen Pifer Nabokov and the Novel adlı kitabından aşağıda alıntılanan cümlelerinde totaliter devletlerin ve onların yöneticilerinin, karşı ve özgün fikirleri olan kişilere yönelik tutum ve davranışları hakkında, bu çalışmanın konusunu oluşturan iki romandaki kahramanlar için de geçerli olan bir genel çerçeve çizer:

Her toplumda o toplumda işleyen kanun ve gelenekleri ihtiyatlı bir şekilde teşvik eden kişiler böyle yapmakla bir menfaat elde ederler. Çünkü bilinçli hayat, doğal olarak siradan gerçekliğin bayă̆ yönlerini teşhir eder, gücü elinde bulunduranlar da kaçınılmaz bir şekilde bilinçli hayatın sınır tanımayan işleyişine düşman kesilirler. Bütün toplumlarda bu bir dereceye kadar bir hakikattir. Fakat totaliter toplumların liderleri bu tür bir teşhire en alt derecede dahi dayanamaz ve bu nedenle ona gösterdiği hoşgörü de en alt seviyededir. Nabokov'un Infaza Çağrı ve Bend Sinister'da gösterdiği gibi özel düşünce halkın düşmanı haline gelir. Totaliter devlette geleneklerin kurallarını zaylflatma ve yaratıcı hassasiyetin canlılığl arasındaki karşıtlık, düpedüz varoluşun kamu ve özel alanı arasındaki, -sıradan gerçeklikle hakiki gerçeklik- arasındaki mücadele haline gelir. Devlet mekanizması bilincin özgür oyunu üzerinde, yakalanması zor bu fiziksel süreç üzerinde savaşı sürdürmek için yıpratma, zorlama ve işkenceyi kullanır. Birçok yönden bu çekişme mantıksal açıdan saçmadır. Düşüncenin tarifsiz doğası kaçınılmaz bir şekilde kendisine gözdă̆l veren devletin maddi gücünü atlatır. Özgür düşünceyi bulma ve harap etme girişiminde bulunan totaliter mekanizma merhametsiz oldugu kadar hantaldır da (Pifer, 1980: 51-52).

Pifer, bu cümlelerinde, özetle, toplumsal hayatı şekillendiren kuralların işleyişine yönelik eleştirinin veya onunla uyuşmama durumunun hiçbir toplumda hoş görülmediğini ancak totaliter devletlerde bu hoşgörüsüzlüğün en katı şekilde ve yine onun tutarsızlığını belgelercesine en saçma yöntemlerle farklı olan/düşünen/davranan bireyler üzerine yöneldiğini dile getirmektedir. Bu perspektiften bakıldığında Dişi Kurdun Rüyaları'nda Abdias'ın tanrı anlayışı noktasında, Boston'un ise koyun yetiştiriciliği konusundaki farklı fikir ve yaklaşımlarının, onların yerleşik düzen ve onun temsilcileriyle çatışma yaşamasına neden olduğu görülmektedir. Abdias, arkadaşı Viktor Nikiforoviç ile yaptığı konuşmada, eski kilise geleneklerinin çağımızla ters düştüğünü, eski zamanlarda, bir toplumun henüz doğuş halindeki bilincine uygun düşen bir doktrini bugün ciddiye almanın mümkün olmadığını belirtir. Ona göre teolojinin varlığını koruyabilmesi için tek çare, dünyadaki bütün inançların odak noktası, merkezi olarak yeni bir tanrı anlayışının ortaya çıkmasından geçmektedir. Abdias'ın Ortodoksluktan kopmasının tek sebebi de günün ihtiyaçlarına cevap veren başka bir iman anlayışını savunmasıdır. 
Bütün çabaları sonuçsuz kalsa bile Tanrı anlayışına çağdaş bir nitelik kazandırmak isteyen Abdias'a, arkadaşı bir başka tanrı aramanın kiliseye karşı işlenmiş en ağır ve bağışlanmaz suçlardan biri olduğunu, bu fikirlerinin kilisenin ileri gelenleri için evreni alt üst etmek anlamına geldiğini belirterek tedbirli olmasını tavsiye eder ve büyük güçlüklerle karşılaşmaya hazır olmasını söyler. Abdias, bu konuşmadan birkaç gün sonra papaz okulunun ileri gelenlerinin garda karşıladıkları Koordinatör Peder de denilen Peder Dimitri ile üç saatlik bir görüşme yapar. Bu görüşmede yüzlerce yıllık uyuşukluktan silkinip kurtulmak, dogmatizmi unutmak ve insana tanrıyı kendi özünün doruğu olarak görme hürriyetini tanımak gerektiğini belirten Abdias, ondan beklediği cevapları alamaz. Peder Dimitri, Abdias'ın tanrı kavramını ıslah etmek şeklindeki düşüncesini eleştirir ve bu düşünceyle aslında Abdias'ın kendisini tanrı yerine koyduğunu belirtir. Abdias kilise kavramını da değişik bir şekilde ele alır, kendi kendisinin kilisesi olduğunu ve papazları bugünkü halleriyle kabul etmeyip tanımadığını belirtir.

Bu sözler aynı zamanda onun kiliseden uzaklaştırılmasına ve artık ekmeğini kendisinin kazanmak zorunda kalmasına yol açar. Bundan sonra "Genç Komünistler" adlı mahalli bir gazetede yazarlık yapan Abdias her ne kadar dergiyi çıkaranlar eski bir papazı din aleyhtarlığı için kullanmak isteseler de kendisi bu işi fikirlerini yaymak ve gençleri dinî meseleler hakkında haberdar etmek için bir firsat olarak değerlendirir. Uyuşturucu kaçakçılarıyla ilgili bir röportaj yapmak ve yayımlamak isteyen Abdias gerekli hazırlıkları yaptıktan sonra bu işe girişir. Uzun tren yolculuğundan sonra onlarla birlikte haşhaş toplar. Birlikte haşhaş topladığı Lenka ve Petruha'ya yaptıkları işin suç olduğunu ve nedamet getirmeleri gerektiğini söyler, ancak onlardan olumsuz bir yanıt alır. Abdias daha uzun ve ayrıntılı bir görüşmeyi ise kaçakçıların başı Grişan ile yapar. O da Abdias'ın görüşlerine şiddetle karşı çıkar, kendilerine yüklü miktarda para sağlayan uyuşturucu kaçakçılığı işinden vazgeçmeye yanaşmaz ve üstelik maiyetindeki diğer kaçakçılara da aynı teklifi yapmakta serbest olduğunu ve kimsenin onun fikirlerini kabul etmeyeceğini belirtir. Olaylar tam da Grişan'ın öngördüğü gibi gelişir. Trene bindikten sonra kendilerine ikram edilen uyuşturucu sigarasını dışarı atan Abdias, yine içinde topladığı uyuşturucuların yer aldığı çantasını da trenin camından atar ve devamında arkadaşlarının da tıpkı kendisi gibi yapmalarını, pişman olmalarını, Tanrı'nın şefkatine sığınmalarını ister. Ancak arkadaşları onu dövmeye başlarlar. Bütün olan biten esnasında Grişan sessiz kalır, Abdias ise yediği dayağa rağmen ondan yardım dilemez ve en sonunda trenden aşağıya da atılır. Yoldan kamyonuyla geçen bir Kazak tarafindan kurtarılan Abdias, istasyona gider ve orada kendilerini dövüp aşağıya atan kaçakçı arkadaşlarının tutuklandığını görür. Onlarla yüzleşmek ister, kendisinin de onlardan biri olduğunu polislere anlatsa da eski arkadaşları onu tanımazlıktan gelir. Çalpak-Saz hastanesine yatırılan Abdias orada haşhaş topladığı köyde gördüğü motosikletli kadınla karşılaşır. Bir botanist olan İnga ile aralarında gönül ilişkisi başlar.

Uyuşturucu kaçakçısı arkadaşlarından sonra bir darbe de röportajı yayımlamak istediği gazeteden gelir. Yazı işleri müdürünün ona ve röportajına karşı davranışı aniden değişir. Çalpak-Saz'a İnga ile buluşmaya giden Abdias evde onu bulamaz ve kendisine birakılan mektupta İnga'nın çocuğunun velayet sorunlarıyla ilgilenmek için Cambul'a gittiğini öğrenir. Tekrar istasyona giden Abdias buradaki polislerden eski kaçakçı arkadaşlarının akıbetini öğrenmeye çalışır. İnga yüzünden depresyona giren Abdias, istasyonda tanıştığı Boss'un teklifini kabul eder. Buna göre plan uygulaması uyarınca et miktarını tutturabilmek için bozkırdaki sayga sürüleri helikopterlerle havadan korkutulup kaçırılacak ve karada arabalar için- 
deki silahlı kişiler tarafından açılan ateşte öldürülerek kamyonlara doldurulup taşınacaktır. Abdias tıpkı uyuşturucu kaçakçılarıyla olan macerasında olduğu gibi bu hayvan katliamına da tepkisiz kalamaz. Ekiptekileri hayvanları öldürmekten vazgeçirmek isteyen ve onları tanrının yoluna davet eden Abdias, Galkin ve Uzukbay adlı kişileri kendi yanına çekmeye çalışır. Elleri bağlanarak ölmüş hayvanların bulunduğu kamyona bırakılan Abdias, votka içmeyi reddeder. Kendisinden tanrıyı inkâr etmesini isterler. Abdias ise tanrının varlığını ikrar eder. Bunun üzerine bir ağaca elleri ve kollar gerili halde bağlanan Abdias ölüme terk edilir. Bir an için gördügünü sandığı Akbar'a seslenerek kendisini kurtarmasını ister. Bir müddet sonra Akbar ve Taşçaynar Abdias'ın ağaca bağlandığı yere gelir. Onu gören Abdias'ın söylediği “-Geldin.. geldin..." (Aytmatov, 1990: 236) şeklindeki ifadeler onun son sözleri olur.

Böylelikle Abdias'ın yeni tanrı anlayışı ne kilise tarafından teorik olarak kabul görmüş ne de pratikte arasına girdiği suç işleyen ve vicdana aykırı işler yapan kişilere karşı geliştirdiği pişmanlık ve doğru yola girme şeklindeki yaklaşımı olumlu bir sonuç vermiştir. Hem teoride hem de pratikte tutarsız ve yanlış bir düzenin savunucuları onu dışlamış, yok saymış ve hatta ölüme terk etmiştir. Abdias bir "non-conformist (konformist-olmayan)" olarak, içinde bulunduğu Sovyet toplumunun konformist yapısının ve onun konformist bireylerinin hedef tahtası haline gelmiştir. Bu çatışmanın kaybedeni Abdias olmuştur.

Abdias'ın temelini din ve ilahiyatın oluşturduğu bir yaklaşımla toplumu dönüştürme yönündeki manevi çabası, Boston örneğinde daha somut veriler üzerinden gerçekleşir. Boston'un düzenin temsilcileri tarafından olumsuz karşılanan farklı fikirleri ve çözüm önerileri vardır. Her firsatta çobanların sürekli olarak ve kendilerininmiş gibi bağlanabilecekleri parsellere sahip olmaları gerektiği görüşünü savunan Boston, konformistleri çileden çıkarır. Boston, yaz mevsiminde, dağlarda sorumluluğu sovhoz kâhyasına değil, kendisine ait olacak yaylaklar ve otlaklar istemektedir. Ona göre beklenmedik güçlükleri, meseleleri halledecek olan kişi kâhya değil, kendisidir. Koyunlarını her yaz ayrı bir yaylaya götürmek istememekte, her zaman kendisinin kullanacağı, başkalarının yararlanamayacağı otlaklarının olmasını arzulamaktadır. Kendisine bu imkânın verilmesi halinde büyük bir üretim artışı olacağını, devletin anonim topraklarda öngördüğü plan hedeflerini aşacağını düşünmektedir. Bu meseleyi her ortaya atışında herkes, önce onu haklı bulur, sonrası ise romanda şu cümlelerle özetlenir:

Ama bu işin olmaması için politikacı bir ekonomistin, bir yardakçının, bu işin sosyalizmin yüce prensipleriyle bağdaşmayacağını, bu konuda şüphesi olduğunu söylemesi yetiyordu. O zaman da meslekdaşları hemen geriye çark eder, sosyalizmden sapma suçlamasından korkarak, birçok tutarsız karşı görüş atarlardı ortaya. (Aytmatov, 1990: 289).

Özellikle de sovhozdaki hücre sekreteri Koçkorbay, Boston’a en çok karşı çıkan kişidir. Koçkorbay şiddetli bir tartışmanın ardından onu mahalli komiteye şikâyet eder. Boston iki toplantıya katılmaz ve hakkında verilecek karara uyacağını belirtir.

Görüldüğü gibi başarılı ve örnek bir çoban olan Boston'un, daha iyi verim alınabilmesi için öne sürdüğü görüşler, Sovyet yönetiminin yeniliğe kapalı ve ilerlemeye engel olan konformist yöneticileri tarafından geçersiz kılınır. Boston'un düzenle çatışması tıpkı Abdias'ın durumunda olduğu gibi yenilgiyle sonuçlanır.

Dişi Kurdun Rüyaları'nda yer alan diğer öyküde, yani Akbar ile Taşçaynar'ın öyküsünde ise düzenle çatışma daha farklı bir boyut alır. Abdias'ın ölürken Akbar'ı çağırıp görmesi 
ve Boston'un ise oğlunu kurtarmak için ateş açarak hem Akbar'1 hem de oğlunu vurması bağlamında, Akbar'ın trajedisinin Abdias ile Boston'unkine eşlik ettiğini, hatta kesiştiğini söyleyebiliriz. Akbar'ın gerçek trajedisi yavrularını bir türlü yaşatamamasıdır. Bunun sebebi de insanların doğadaki dengeyi dikkate almaksızın, doğal hayatı vahşice yok etmeleri, ekolojik düzeni bozmalarıdır. Akbar'ın öyküsünde ekolojik düzen, insanların müdahalesiyle bozulmuş, insanların vahşi hırslarına ve arzularına endeksli belirsiz, tekinsiz, eskinin aksine öngörülemeyen bir düzen halini almıştır. Abdias ve Boston'u dışlayan anlayış Akbar'a da neslini sürdürme şansı vermez. Özellikle Bazarbay'ın kurt yavrularını inlerinden almalarını eleştiren Boston’un Koçkorbay'dan aldığı şu yanıt oldukça dikkat çekicidir:

Daha geçenlerde, çobanlarımızdan biri olan Bazarbay Novgutov dağda bir kurt ini buldu ve dört kurt yavrusuna el koydu. Böylece kurt sürüsünü kökünden kurutmak için yapılması gerekeni yaptı. (Aytmatov, 1990: 324)

$\mathrm{Bu}$ sözlerin bir devlet yetkilisi tarafindan söylenmesi son derece anlamlıdır. Böylelikle kurt yavrularının inlerinden alınması ve soylarının tükenmesi sistemin istediği bir durum olarak dile getirilmiştir. Bu sözler, Akbar'ı düzenle çelişme ve karşıtlık noktasında da konumlandırmış olmaktadır.

Nabokov'un Infaza Çăgrı'sında ise başkahraman Cincinnatus C. mahkeme tarafından idama mahkûm edilir. Roman onun idam hükmünün bildirilmesiyle başlar ve idam sehpasına uzanıp akabinde oradan kalkmasıyla da biter. Romanın distopik dünyası içinde Cincinnatus'un suçu, geçirimsizlik, saydamsızlık ve kapalılık gibi kelimelerle de tarif edilen “bilinirci alçaklık”tır. (Nabokov, 1990: 46)

Cincinnatus'u idama götüren yolun taşları ise zamanla döşenmiştir. Bu bakımdan romanda bir yandan Cincinnatus C.'nin hücrede geçirdiği günler anlatılırken, bir yandan da hücreye girmeden önceki hayatının çeşitli ayrıntıları aktarılır. İşte bu ayrıntıların bir kısmı da Cincinnatus'u idama götüren sürece ilişkindir. Buna göre saydamsızlık, Cincinnatus'un özenle gizlemeyi başardığı bir özelliğidir ve çevresindekiler de onun saydamsızlığını sezmişçesine davrandıklarında ise Cincinnatus, kendi öz benliğini bağrına basıp güvenli bir yere götürür.

Kimliği bilinmeyen bir yabancının oğlu olan ve çocukluğu bir bakım evinde geçen Cincinnatus çocukluk çağından itibaren saydamsızlık özelliğini ortaya koyan olaylar yaşar ve ihbar edilir. Önce bir oyuncak atölyesinde çalışan Cincinnatus, 22 yaşında ise bir anaokulu öğretmeni olur ve hakkında şikâyette bulunulur. Onu birtakım sınavlardan ve testlerden geçirirler. Genç ve dinç olduğu bu dönemde bunların üstesinden gelir. Ancak zamanla kendini kollamaz ve kent parkında vuku bulan bir hadiseden 10 gün sonra tutuklanır.

Cincinnatus'un suçuna ilişkin çevresinden gelen tepkiler de dikkat çekicidir. Marthe ve ailesi yaptıkları ziyarette, Marthe'nin babası Cincinnatus'u suçlar, böyle bir şeyi nasıl ve ne cüretle yapabildiğini sorar. Öte yandan Cincinnatus'un kayınbiraderi ise kendisinin hatırı için tövbe etmesini, belki de onu salıverebileceklerini söyler. Son görüşmelerinde aynı teklifi Marthe de yapar.

Cincinnatus Marthe'ye Dur, Marthe, anlamiyorsun. Neye tövbe edecekmişim? (Nabokov, 1990: 127) diye sorar. Marthe, tövbe etmesi konusunda üstelemeye devam eder. Cincinnatus'un tavrı yine aynıdır. Marthe'ye yazdığı mektupta Cincinnatus, kendi çevresinin kuklalarla sarıldığını ve hatta Marthe'nin bile bir kukla olduğunu belirtir. 
Hücresinde yazı yazmaya başlayan Cincinnatus, kendisinin farklı oluşu noktasında ise şu değerlendirmeyi yapar:

Bildiğim bir şey var, bildiğim bir şey var, bildiğim... Daha çocukken, beni ve yüzlerce başka çocuğu, yaşıtlarımın hiç zorlanmadan, acı çekmeden dönüşüverdikleri yetişkin birer kukla olarak güvenli var olmayışa hazırladıkları kocaman, kanarya sarısı, soğuk bir evde yaşarken; daha o zaman, o kahrolası günlerde, bez kitaplar, alacalı bulacalı okul gereçleri, ruhu donduran cereyanlar arasında bilmeden biliyordum, şaşmadan biliyordum, kişi kendini nasıl bilirse öyle biliyordum, bilinmesi olanaksı olanı biliyordum, -üstelik bugünden daha büyük bir açıklıkla bildiğimi bile söyleyebilirim, çünkü hayat beni yıprattı: Sürekli tedirginlik, bilgimi gizlemek, yalan içinde yaşamak, korku, düş kırıklı̆̆ yaratmamak, avaz avaz ilan etmemek için sinirlerimin acı zorlanışı... (Nabokov, 1990: 61).

Devamında belleğinde bu çabanın başlangıcını teşkil eden, kendine doğal görünen şeylerin gerçekte yasak, imkânsız olduklarını, onları düşünmenin suç sayıldığını anlamasına neden olan ilk olayı anımsar.

Sıra dışılık yalnızca Cincinnatus’un özelliği değildir. Romanda olayların geçtiği toplum yapısı ve mekân da benzer özellikler taşır. Carl R. Proffer, romandaki toplum yapısı ve mekânın gerçekdışı oluşunun yalnızca herhangi bir özel toplum yapısına modellik etmemesinden kaynaklanmadığını, bunun yanı sıra romandaki toplumun dünyadaki herhangi bir toplumun dişında bir karakter gösterdiğini belirtir (Proffer, 1982: 55). Yine ona göre zaman olarak bir gelecek dünyası hayal edilmiştir (Proffer, 1982: 55). Proffer, romanın geleceği ele alışı ve bilim kurgu özelliklerinin, elektrikli cenaze arabası, kuğu biçimli elektrikli vagonlar ve onların içtikleri ‘sabayon' gibi şeylerin sunumuyla belirtildiğini, insanların saydam olabildikleri denli uzak bir geleceğin tasvir edildiğini ifade eder (Proffer, 1982: 55).

Tutuklu olduğu dönemde Cincinnatus, ne zaman idam edileceğini öğrenmeye çalışır. Karısı Marthe ile önce görüşmek ister, akabinde mektubunun ona ulaştırılmasını talep eder. Bir diğer kaygısı da hücrede yazdığı yazıların akıbetidir. Yine hücrede bulunduğu dönemde yer yer komik, çoğu kez saçma nitelikli uygulamalarla karşılaşır. İdam hükmünün mahkeme salonunda kulağına fisıldanarak söylenmesinden sonra hücrede asılı duran mahkûmlarla ilgili yönergenin maddeleri son derece saçmadır. İlk başta mahkûm gibi görünen sonra cellat olduğu anlaşılan Mösyö Pierre'in hücresinden kendi hücresine bir tünel kazıldığını anlar. Üstelik Mösyö Pierre ile hapishane müdürü birlikte kazmışlardır bu tüneli ve Cincinnatus Mösyö Pierre'in hücresinden bu tünelden geçerek dönerken birdenbire kendini kalenin d1şında bile bulabilmiştir. Yine idamdan önce Cincinnatus ile Mösyö Pierre'in gayri resmi bir akşam yemeği için kent yönetici yardımcısının evinde toplanmaları kararlaştırılır. Terastan tam gece yarısı parkta otların ve çalıların arasında en az bir milyon ampulden oluşan $\mathrm{P}$ ve $\mathrm{C}$ harflerinin görüntüsünü veren 1şıklar 3 dakika boyunca yanar. Son sahnede Avukat Roman Vissarionoviç'in Rom, Müdür Rodrig İvanoviç'in ise Rod olarak cellat Mösyö Pierre tarafından kendisinin yardımcıları olarak adlandırıldığını görürüz.

Bütün bu örnekler böylesine sıra dışı bir toplum ve kamu düzeni içinde yaşayan Cincinnatus’un yalnızlığını ve ümitsizliğini ortaya koyar. Ancak romanda öteki dünyanın varlığını duyuran bir 'hava akımı'ndan da söz etmek gerekir. Cincinnatus'un çocukluk dönemindeki sıra dışı deneyiminde hava akımı ve havayı hissetme önemli bir motif olarak yer almaktadır. Sonrasında romanda bu hava akımının Cincinnatus'un üzerindeki etkisi şu şekilde ifade edilir: 
Sanki benliğinin bir yanı, hani olanca karmaşıklıklarıyla bir ăgacın yaprakları karartıdan aydınlığa geçiverirler ve insan bir başka öğenin ışıltısına gömülüş tam olarak nerede başlar bir türlü çıkartamaz ya öyle, bir başka boyuta kayıveriyordu. Sanki Cincinnatus gelişigüzel kotarılmış hücrenin kısıtlı mekânındaki devinimleri sırasında her an kendisini havadaki bir yarıktan doğalca, kolayca, onun bilinmez perde arkasına geçiriverecek bir adım atacak ve döndürülen bir aynanın yanar döner yansısı nasıl odadaki tüm nesnelerin üstünden geçip adeta havanın ardında, esirin yeni bir derinliğinde apansız yiterse, aynı zahmetsiz akıcılıkla orada gözden kaybolacak sanırdınız (Nabokov, 1990: 77).

Burada hava akımının, kahramanı başka bir boyuta geçirmesinin bir örneğini Cincinnatus'un hücresine konan büyük kelebeğin hava akımıyla birlikte, sanki hava onu yutmuşçasına ortadan kaybolmasında görürüz. Romanın sonunda da Cincinnatus idam sehpasından kalkar, hortumsu bir rüzgârın bütün platformu ve dünyayı dağıttı̆̆ı ve biraz da belirsiz bir şekilde tasvir edilen bu final sahnesinde "kendine benzeyen varlıkların arasına" gider.

Öte yandan Cincinnatus, kendisinin yazılmış bir eserin kahramanı olduğunun da bilincindedir ve kendisine son isteği sorulduğunda verdiği cevapta bunu açık bir şekilde ortaya koyar:

Yazdı̆̆ım bir şeyi bitirmek. diye fisıldadı Cincinnatus, sorarcasına, ama sonra kaşlarını çattı, düşüncelerine çeki düzen verdi ve birden her şeyin zaten yazılmış olduğunu anladı (Nabokov, 1990: 133).

Böylelikle bütün anlatılanların bir kurgu olduğu belirtilerek, bu distopik eserdeki saçmalıklar, komiklikler ve abartıları gerçek hayatla ve gerçek bir ülkeyle birebir eşleştirme şeklindeki bir yaklaşıma burada bir kez daha ket vurulur. Bununla birlikte eserin, yazarın kendi kişisel tarihi ve yazıldığg dönem itibariyle, onun göçmenliğinin de müsebbibi olan Sovyet yönetiminin ve romanı yazarken içinde yaşadığı Nazi Almanya'sının dolaylı bir eleştirisi olarak okunmaya uygun olduğunu belirtmek gerekir. Cincinnatus'un trajedisinin "ideası", gerçek hayatta bu ülkelerde toplumun genelinden farklı olan bireylerin trajedileri bağlamında sayısız "gölge"ye sahiptir.

Her iki romanın yerleşik düzenle çatışma noktasında karşılaştırdığımızda Dişi Kurdun Rüyaları'nda Abdias ve Boston'un yerleşik düzenin hatalı yanlarını onarmaya, yanlış uygulamaları ve durumları ortadan kaldırmaya çalıştıkları görülür. Yerleşik düzenin devamını öngören hâkim konformist yaklaşım ve onun toplumdaki temsilcileri yerleşik düzeni koruma adına kendilerini savunur ve onları bertaraf eder. Akbar'ın öyküsü ise yerleşik düzenin ekolojik düzeni de ortadan kaldırmaya yeltendiğini göstermesi açısından dikkat çekicidir. Cincinnatus'un içinde bulunduğu toplum yapısı da kendi anlayışı uyarınca farklı bir birey olan Cincinnatus'un idamını gerekli görür. Cincinnatus'un bilerek işlediği bir suç yoktur, kendisine atfedilen saydamsızlık suçlaması onun kendi tabiatının bir sonucudur. Ancak toplumsal yapı ve onun resmi görüntüsü öylesine mantık dışı kodlarla donanmıştır ki Cincinnatus bu maddi düzenin içinde herhangi bir çözüm imkânının olmadığının bilincindedir. Proffer'in de belirttiği gibi onu bu durumdan kurtarabilecek tek güç muhayyiledir:

Sonunda Cincinnatus'un kendi zihni özgürleştirici son atılımı yaptığında muhayyilenin, cellatlarından kurtulmasını da içeren birtakım şeyleri yapmak için kendisini özgürleştirdiğini anlar. Cincinnatus, bütün roman boyunca parlak bir dünya hayalini, öteki boyutu ve bu öteki boyuta nasıl girebileceğinin merakını muhafaza eder. Son paragraflarda bunu başarır da (Proffer, 1982: 55). 
Kısacası Cincinnatus onarılamaz ve onarmayı düşünmediği bir dünyadan kurtuluşu romanın mantığ 1 içinde muhayyilesinin gücüyle başka bir boyuta geçmekte bulur, zaten ardı sıra kendisini mahkûm eden dünya da yıkılır. Nabokov bu yıkımı rahatlıkla yapabilmiştir, çünkü eserini gerçekliğin ve tarihin determinizminden kurtaran bir distopya tasarımı içinde kurgulamıştır. Dişi Kurdun Rüyaları ise bir distopya değildir. Doğrudan doğruya Sovyet toplumunun kimi yönlerinin eleştirisini içerir ve Aytmatov, Infaza Çă̆rl'da Nabokov'un yaptığı gibi, romandaki dünyayı yıkmaz, yıkamaz. Çünkü Dişi Kurdun Rüyaları'nın kurgu dünyasının yansımasını oluşturduğu gerçeklik böyle bir eylem için yazara bir imkân sunmaz. Gerçekliğin ve tarihin determinizmine tabi olan Dişi Kurdun Rüyaları'nda yaşamın her şeye karşın devam ettiği duygusu sezdirilir. Aytmatov'un romanda yapamadığını ise tarih yapmış, tıpkı Nabokov'un Infaza Çağrısı'ndaki yıkılan dünya gibi, Sovyet düzenini ortadan kaldırmış ve bu açıdan da Nabokov'u haklı çıkarmıştır.

\section{Sonuç}

Her iki eserde de farklı bireylerin, herkesin birbirine benzediği bir toplum tarafından dışlanması, suçlanması ve hatta ölüme mahkûm edilmesi şeklinde özetlenebilecek bir temel hikâye yer almaktadır. Metinlerinde uyguladıkları stratejiler farklı olsa da iki yazarın da 20. yüzyılın baskıcı rejimlerinin altında yaşamak zorunda kalan ve toplumun genelinden farklı olan bireylerin haklılı̆̆ını dile getirmenin arayışında olduklarını belirtmek gerekir. $\mathrm{Bu}$ bağlamda, başta Beyaz Gemi ve Gün Olur Asra Bedel olmak üzere birçok eserinde tarihten ve mitolojiden yararlanan Aytmatov, bu romanında da Hz. İsa'ya ve onun dönemine kadar uzanan bir perspektiften istifade ederek evrensel ve kökleri tarihte olan bir duyarlılığ dile getirmeye yönelir. Aytmatov eleştirmek istediği düzeni doğrudan hedef alır ve tarihe yönelirken, Nabokov totaliter yönetimlere yönelik eleştirisini dolaylı bir anlatımla yapar. İnfaza Çăgrı'da, bir distopya tasarımı ve görünüşte herhangi bir ülkeyi hedef almadan ancak gerçekte o dönemdeki totaliter ülkeleri, özellikle SSCB ve yazarın romanı yazarken Berlin'de içinde yaşadığı Nazi Almanya'sını akla getirecek bir toplumsal yaşam ve idarî düzenin içinde kendi kahramanını konumlandırır; bu kahramanı infaz etmek isteyen dünyayı da yıkıp baskıcı rejimlerinin mutlak akıbetini göstererek varmak istediği genellemeye bu şekilde ulaşır.

\section{Kaynaklar}

Aytmatov, C. (1990). Dişi kurdun rüyaları. (çev. R. Özdek) İstanbul: Ötüken.

Kolcu, A.İ. (2008). Bozkırdaki bilge. (3bs.). Erzurum. Salkımsöğüt.

Nabokov, V. (1989). Infaza çă̆rı. (çev. S. Akar) İstanbul: Ayrıntı.

Nabokov, V. (1963). Invitation to a beheading. (D. Nabokov, çev.) London: Penguin.

Pifer, E. (1980). Nabokov and the novel. USA: Harvard University.

Pitzer, A. (2014). Vladimir Nabokov yazarın gizli tarihi. (çev. Y. Yavuz,). İstanbul: İletişim.

Proffer, C.R. (1982). The double life of Vladimir Nabokov. American Writing Today, R. Kostelanetz (Ed.), vol.1, (s. 51-61). Washington: Forum Series. 